\title{
The effects of daily chlorhexidine bathing on cutaneous bacterial isolates: a pilot study
}

This article was published in the following Dove Press journal:

Infection and Drug Resistance

21 April 2012

Number of times this article has been viewed

Vijaya L Soma'

Xuan Qin ${ }^{2}$

Chuan Zhou'

Amanda Adler'

Jessica E Berry²

Danielle M Zerr'

'Department of Pediatrics,

${ }^{2}$ Department of Laboratory

Medicine, University of

Washington, Seattle, WA, USA
Correspondence: Vijaya L Soma

Division of Pediatric Infectious Diseases, Steven and Alexandra Cohen Children's Medical Center of New York, 269-0I 76th Avenue, New Hyde Park,

NY I 1040, USA

Tel +I 7I847034I5

Fax +I 7184700887

Email vsomal@nshs.edu

\begin{abstract}
Chlorhexidine gluconate $(\mathrm{CHG})$ is a topical antiseptic used in a myriad of clinical settings. Recently, CHG baths have been shown to decrease multidrug-resistant organism acquisition and infections and catheter-associated bloodstream infections. The present study examined the effects of daily bathing with $\mathrm{CHG}$ on the recovery and antimicrobial susceptibility of cultivable cutaneous bacteria. The objectives of this study were to (1) explore the effects of clinical CHG bathing on cultivable cutaneous bacteria, (2) study the relationship between CHG minimum inhibitory concentration and antimicrobial susceptibility of coagulase-negative staphylococci, and (3) demonstrate the feasibility of the approach so a more definitive study may be performed. Significant decreases in bacterial colony counts and phenotypic diversity occurred with greater $\mathrm{CHG}$ exposure. The findings also suggest an inverse relationship between CHG minimum inhibitory concentration and antimicrobial susceptibility. Larger prospective studies are necessary to fully investigate the clinical impact of CHG usage.
\end{abstract}

Keywords: antiseptic, resistance, Staphylococcus, coagulase-negative

\section{Introduction}

Chlorhexidine gluconate $(\mathrm{CHG})$ is a topical antiseptic used in a myriad of clinical settings. Recently, CHG baths have been shown to decrease multidrug-resistant organism acquisition and infections and catheter-associated bloodstream infections. ${ }^{1,2}$

Limited in vitro data suggest that some organisms develop elevated minimum inhibitory concentrations (MICs) to CHG with continued exposure. ${ }^{3}$ In Staphylococcus aureus, the qacA plasmid-borne resistance determinant is associated with efflux of CHG from bacteria ${ }^{4}$ and with antimicrobial resistance. ${ }^{3,5-7}$ Clinical data are needed to better understand the extent to which regular clinical $\mathrm{CHG}$ exposure is associated with elevated CHG MICs and reduced susceptibility to other antimicrobials. Furthermore, most prior studies focus on qacA activity in $S$. aureus, although coagulase-negative staphylococci (CoNS) commonly cause catheter-associated infections.

The objectives of this study were to (1) explore the effects of clinical CHG bathing on cultivable cutaneous bacteria, (2) study the relationship between CHG MIC and antimicrobial susceptibility of CoNS, and (3) demonstrate the feasibility of the approach so a more definitive study may be performed.

\section{Materials and methods}

In the authors' hospital, Seattle Children's Hospital (Seattle, WA), patients with central lines are "bathed" daily by wiping their skin, from the neck down, with a $2 \% \mathrm{CHG}$ impregnated cloth (Sage Products, Inc, Cary, IL). Pediatric patients were eligible 
for study enrollment if they were aged 2 months or older, hospitalized between November 2010 and April 2011, and scheduled to receive daily $\mathrm{CHG}$ baths.

Samples were obtained by rubbing a saline-moistened sterile nylon-flocked swab (Copan Diagnostics Inc, Murrieta, CA) over a $9 \mathrm{~cm}^{2}$ area of skin for 30 seconds. Patients were swabbed in the right axilla weekly until discharge, and the same researcher performed the swabbing each time. Swabs were vortexed in normal saline and aliquots were inoculated onto the following agars: sheep blood, chocolate, mannitol salt, MacConkey, and Sabouraud dextrose. Plates were incubated at $35^{\circ} \mathrm{C}$ and checked for growth by 48 hours; any growth was subcultured and identified as CoNS, S. aureus, Streptococcus pneumoniae, Enterococcus spp, viridans streptococci, group A streptococci, Bacillus spp, diphtheroids, yeast, or gram-negative (no further analysis of gram-negative organisms). ${ }^{8}$ The total colony count of a swab was obtained from the blood agar plate.

CoNS isolates underwent antimicrobial susceptibility testing and were classified as susceptible or nonsusceptible using Clinical and Laboratory Standards Institute recommendations. ${ }^{9}$ Antimicrobials tested were penicillin $(10 \mu \mathrm{g})$, amoxicillin-clavulanate $(20 / 10 \mu \mathrm{g})$, cefazolin $(30 \mu \mathrm{g})$, cefoxitin $(30 \mu \mathrm{g})$, ceftriaxone $(30 \mu \mathrm{g})$, clindamycin $(2 \mu \mathrm{g})$, erythromycin $(15 \mu \mathrm{g})$, gentamicin $(10 \mu \mathrm{g})$, trimethoprim-sulfamethoxazole $(1.25 / 23.75 \mu \mathrm{g})$, ciprofloxacin $(5 \mu \mathrm{g})$, rifampin $(5 \mu \mathrm{g})$, linezolid $(30 \mu \mathrm{g})$, and vancomycin (range $0.016-256 \mu \mathrm{g} / \mathrm{mL}$ ). Vancomycin susceptibility was determined by Etest ${ }^{\circledR}$ (bioMérieux, Inc, Durham, NC); susceptibility to all other antibiotics was determined by disk diffusion. CHG MIC testing was conducted using a 96-well broth microdilution method. ${ }^{9}$ Quality control organisms were included in each panel.

Polymerase chain reaction (PCR) amplification for $q a c A / B$ was performed with the GeneAmp ${ }^{\circledR}$ system (Applied Biosystems, Carlsbad, CA), using primers for sequences conserved between the two genes. ${ }^{10}$ To distinguish qacA from $q a c B$ - which does not encode a CHG efflux pump - initial $q a c A / B$ PCR products were digested with the $A l u I$ restriction enzyme; qacA and $q a c B$ fragments were detected by agarose gel electrophoresis. ${ }^{10}$ Appropriate positive and negative control isolates were used in each step.

Every swab obtained was categorized into one of the following $\mathrm{CHG}$ exposure groups: none (no $\mathrm{CHG}$ exposure), moderate (1-14 daily CHG baths), and heavy ( $>14$ daily $\mathrm{CHG}$ baths). Some patients contributed swabs to more than one exposure group; therefore, analyses were based on $\mathrm{CHG}$ exposure of the swabs, rather than that of the patients. To minimize the possibility of one patient's specimens heavily influencing the overall results, each patient was allowed to contribute only one swab per CHG exposure group for analyses of total colony and phenotype counts. If a patient had more than one swab in an exposure category, only the swab with the greatest CHG exposure was included. Similarly, each patient was allowed to contribute one CoNS isolate per $\mathrm{CHG}$ exposure category for analyses of $\mathrm{CHG}$ MIC. If a patient had more than one isolate in an exposure category, only the isolate with the highest $\mathrm{CHG}$ MIC was included. Lastly, for analyses of antimicrobial susceptibility versus $\mathrm{CHG} \mathrm{MIC}$, patients were allowed to contribute one CoNS isolate per $\mathrm{CHG}$ MIC category $(\leq 1 \mu \mathrm{g} / \mathrm{mL}$ or $\geq 2 \mu \mathrm{g} / \mathrm{mL}$ ).

The authors compared bacterial colony counts per swab and number of bacterial phenotypes per swab across exposure groups using the Kruskal-Wallis test. The presence of antimicrobial susceptibility across exposure groups was evaluated using Fisher's exact test. Statistical analyses were performed using Stata (v 10.0; StataCorp LP, College Station, TX).

\section{Results}

Twenty-four patients were enrolled in the study. An equal number of male and female participants were involved, and participants had a mean age of 5.7 years (range from 2 months to 19 years). Ultimately, four, fifteen, and ten swabs and three, eleven, and four individual CoNS isolates were included in the "none," "moderate," and "heavy" CHG exposure groups, respectively (Table 1). In the moderate and heavy exposure groups, the mean number of days receiving

Table I Chlorhexidine gluconate (CHG) exposure versus measured outcomes

\begin{tabular}{|c|c|c|c|c|c|}
\hline CHG exposure & $\begin{array}{l}\text { Swabs } \\
\text { (n) }\end{array}$ & $\begin{array}{l}\text { Bacterial colony } \\
\text { count per swab }\end{array}$ & $\begin{array}{l}\text { Bacterial phenotypes } \\
\text { per swab }(n)^{a}\end{array}$ & $\begin{array}{l}\text { CoNS } \\
\text { isolates (n) }\end{array}$ & $\begin{array}{l}\text { CHG MIC }_{50} \\
(\mu \mathrm{g} / \mathrm{mL})^{a}\end{array}$ \\
\hline None & 4 & $5145(15-12870)$ & $2(1-3)$ & 3 & $I(I-2)$ \\
\hline Moderate (I-I4 CHG baths) & 15 & $15(0-30750)$ & I (0-3) & II & I $(0.5-2)$ \\
\hline Heavy (>14 CHG baths) & 10 & $0(0-7500)$ & $0(0-1)$ & 4 & $1.5(I-4)$ \\
\hline
\end{tabular}

Notes: aMedian values provided; numbers in parentheses reflect range values.

Abbreviations: CoNS, coagulase-negative staphylococci; $\mathrm{MIC}_{50}$, median minimum inhibitory concentration. 
CHG baths was 7.5 (range 1-14) and 51.6 (range 17-139), respectively (data not shown).

Median bacterial colony count per swab decreased from 5145 (range 15-12, median 870) to 15 (range 0-30, median 750) to 0 (range 0-7500) for the "none," "moderate," and "heavy" CHG exposure groups, respectively $(P=0.03)$. The median number of phenotypically different bacteria per swab also decreased across exposure groups: 2 (range 1-3), 1 (range $0-3)$, and 0 (range $0-1)$, respectively $(P=0.02)$ (Table 1).

The median CHG MIC was $1 \mu \mathrm{g} / \mathrm{mL}$ for both low and moderate $\mathrm{CHG}$ exposure groups (range $1-2$ and $0.5-2 \mu \mathrm{g} / \mathrm{mL}$, respectively) and $1.5 \mu \mathrm{g} / \mathrm{mL}$ (range $1-4 \mu \mathrm{g} / \mathrm{mL}$ ) for the heavy exposure group $(P=0.35)$ (Table 1$)$.

All CoNS isolates were susceptible to vancomycin, linezolid, and rifampin. Except for penicillin, antimicrobial susceptibility was more frequent in isolates in the lower $\mathrm{CHG}$ MIC group ( $\mathrm{MIC} \leq 1 \mu \mathrm{g} / \mathrm{mL}$ ) than in the higher CHG MIC group (MIC $\geq 2 \mu \mathrm{g} / \mathrm{mL}$ ) (Table 2 ). Eighty percent of isolates in the higher MIC group were found to be resistant to three or more antimicrobials, compared with only $27 \%$ of isolates in the lower MIC group $(P=0.11)$.

Of 17 tested CoNS isolates, eleven (65\%) carried $q a c A / B$. Ten of these isolates carried qacA specifically; AluI digestion was unsuccessful for one PCR product. qacA was detected in $100 \%$ of isolates in the higher CHG MIC group and in $45 \%$ of isolates in the lower MIC group ( $P=0.09$ ); 50\% of qacA-positive isolates had $\mathrm{CHG} \mathrm{MICs} \geq 2 \mu \mathrm{g} / \mathrm{mL}$.

Table 2 Comparison of antimicrobial susceptibility in isolates with a minimum inhibitory concentration of chlorhexidine gluconate $(\mathrm{CHG}$ MIC) $\leq \mathrm{I} \mu \mathrm{g} / \mathrm{mL}$ and isolates with a CHG MIC $\geq 2 \mu \mathrm{g} / \mathrm{mL}$

\begin{tabular}{|c|c|c|c|}
\hline \multirow{2}{*}{$\begin{array}{l}\text { Antimicrobial } \\
\text { agent }\end{array}$} & \multicolumn{2}{|c|}{$\%$ susceptible to specified agent ${ }^{a}$} & \multirow[t]{2}{*}{$P$-value ${ }^{b}$} \\
\hline & $\begin{array}{l}\text { CHG } \\
\text { MIC } \leq I \mu \mathrm{g} / \mathrm{mL} \\
(\mathrm{n}=\mathrm{II})\end{array}$ & $\begin{array}{l}\text { CHG } \\
\text { MIC } \geq 2 \mu \mathrm{g} / \mathrm{mL} \\
(n=5)\end{array}$ & \\
\hline $\begin{array}{l}\text { Amoxicillin- } \\
\text { clavulanate }\end{array}$ & 100 & 80 & 0.31 \\
\hline Cefoxitin & 72 & 20 & 0.11 \\
\hline Cefazolin & 100 & 20 & 0.003 \\
\hline Ceftriaxone & 72 & 40 & 0.30 \\
\hline Ciprofloxacin & 100 & 20 & 0.003 \\
\hline Clindamycin & 91 & 20 & 0.01 \\
\hline Erythromycin & 45 & 20 & 0.59 \\
\hline Gentamicin & 100 & 40 & 0.02 \\
\hline Penicillin & 18 & 20 & 0.99 \\
\hline $\begin{array}{l}\text { Trimethoprim- } \\
\text { sulfamethoxazole }\end{array}$ & 72 & 20 & 0.11 \\
\hline
\end{tabular}

Notes: aAll isolates were susceptible to vancomycin, linezolid, and rifampin; bfom Fisher's exact test.

\section{Discussion}

In a sample of pediatric patients with central lines and receiving daily $\mathrm{CHG}$ baths, greater $\mathrm{CHG}$ exposure was associated with lower colony counts of cultivable cutaneous bacteria and fewer different bacterial phenotypes. CoNS isolates with elevated CHG MICs were significantly less susceptible to several antimicrobials.

With increasing clinical use of $\mathrm{CHG}$, there is concern that organisms may develop reduced susceptibility to the antiseptic and to other antimicrobials. ${ }^{3}$ A slight increase was observed in the median CHG MIC of cutaneous CoNS for the highest exposure group, but the difference was not significant. Similarly, while qacA was detected more frequently in CoNS with higher $\mathrm{CHG} \mathrm{MICs}$, the difference was not significant. However, it was found that the frequency of antimicrobial nonsusceptibility was significantly higher among CoNS with higher CHG MICs, suggesting an association between $\mathrm{CHG}$ $\mathrm{MIC}$ and resistance determinant(s) in CoNS. Prior studies most clearly demonstrate plasmid-based linkages between $q a c A / B$ and beta-lactamase genes. ${ }^{5,6}$ Another possible explanation is that antimicrobial resistance is, in part, mediated by the QacA efflux pump.

This study was limited by its observational design and small convenience sample. The small sample size limited the ability to detect significant differences in median $\mathrm{CHG}$ $\mathrm{MIC}$ and presence of qacA among the different exposure groups. Nevertheless, this study is unique in its emphasis on clinical CHG use and suggests important hypotheses for future confirmatory studies.

\section{Conclusion}

The authors observed significant decreases in cultivable cutaneous bacterial colony counts and the number of phenotypes with increased $\mathrm{CHG}$ exposure. While the data did not demonstrate a clear association between $\mathrm{CHG}$ exposure and CHG MICs, the findings support an inverse relationship between CHG MIC and antimicrobial susceptibility in CoNS. Larger prospective studies are necessary to fully investigate the clinical impact of $\mathrm{CHG}$ usage.

\section{Acknowledgments}

The authors thank Dr Nobumichi Kobayashi for providing positive control isolates. The National Institutes of Health (5T32HD007233-28) supported this work financially.

\section{Disclosure}

Dr Zerr received research funding from Sage Products, Inc. The other authors report no conflicts of interest in this work. 


\section{References}

1. Climo MW, Sepkowitz KA, Zuccotti G, et al. The effect of daily bathing with chlorhexidine on the acquisition of methicillin-resistant Staphylococcus aureus, vancomycin-resistant Enterococcus, and healthcare-associated bloodstream infections: results of a quasi-experimental multicenter trial. Crit Care Med. 2009;37(6):1858-1865.

2. Bleasdale SC, Trick WE, Gonzalez IM, Lyles RD, Hayden MK, Weinstein RA. Effectiveness of chlorhexidine bathing to reduce catheterassociated bloodstream infections in medical intensive care unit patients. Arch Intern Med. 2007;167(19):2073-2079.

3. Vali L, Davies SE, Lai LL, Dave J, Amyes SG. Frequency of biocide resistance genes, antibiotic resistance and the effect of chlorhexidine exposure on clinical methicillin-resistant Staphylococcus aureus isolates. J Antimicrob Chemother. 2008;61(3):524-532.

4. Littlejohn TG, Paulsen IT, Gillespie MT, et al. Substrate specificity and energetics of antiseptic and disinfectant resistance in Staphylococcus aureus. FEMS Microbiol Lett. 1992;74(2-3):259-265.

5. Sidhu MS, Heir E, Leegaard T, Wiger K, Holck A. Frequency of disinfectant resistance genes and genetic linkage with beta-lactamase transposon Tn552 among clinical staphylococci. Antimicrob Agents Chemother. 2002;46(9):2797-2803.
6. Sidhu MS, Heir E, Sørum H, Holck A. Genetic linkage between resistance to quaternary ammonium compounds and beta-lactam antibiotics in food-related Staphylococcus spp. Microb Drug Resist. 2001;7(4): 363-371.

7. Zhang M, O’Donoghue MM, Ito T, Hiramatsu K, Boost MV. Prevalence of antiseptic-resistance genes in Staphylococcus aureus and coagulasenegative staphylococci colonising nurses and the general population in Hong Kong. J Hosp Infect. 2011;78(2):113-117. Epub April 19, 2011.

8. Murray PR, Baron EJ. Manual of Clinical Microbiology. 9th ed. Washington, DC: ASM Press; 2007.

9. Cockerill FR; for Clinical and Laboratory Standards Institute (CLSI). Performance Standards for Antimicrobial Susceptibility Testing: Twentieth Informational Supplement. Wayne, PA: CLSI; 2010.

10. Alam MM, Kobayashi N, Uehara N, Watanabe N. Analysis on distribution and genomic diversity of high-level antiseptic resistance genes qacA and qacB in human clinical isolates of Staphylococcus aureus. Microb Drug Resist. 2003;9(2):109-121.

\section{Publish your work in this journal}

Infection and Drug Resistance is an international, peer-reviewed openaccess journal that focuses on the optimal treatment of infection (bacterial, fungal and viral) and the development and institution of preventive strategies to minimize the development and spread of resistance. The journal is specifically concerned with the epidemiology of antibiotic

\section{Dovepress}

resistance and the mechanisms of resistance development and diffusion in both hospitals and the community. The manuscript management system is completely online and includes a very quick and fair peerreview system, which is all easy to use. Visit http://www.dovepress.com/ testimonials.php to read real quotes from published authors. 